\title{
Tillage and Fertilizer Management Effects on Soil-Atmospheric Exchanges of Methane and Nitrous Oxide in a Corn Production System
}

\author{
Ermson Z. Nyakatawa, ${ }^{1}$ David A. Mays, ${ }^{1}$ Thomas R. Way, ${ }^{2}$ Dexter B. Watts, ${ }^{2}$ \\ Henry A. Torbert, ${ }^{2}$ and Douglas R. Smith ${ }^{3}$ \\ ${ }^{1}$ Department of Natural Resources and Environmental Sciences, Alabama A\&M University, P.O. Box 1208, Normal, AL 35762, USA \\ ${ }^{2}$ USDA-ARS, National Soil Dynamics Laboratory, 411 South Donahue Drive, Auburn, AL 36832, USA \\ ${ }^{3}$ USDA-ARS-MWA, National Soil Erosion Research Laboratory, 275 South Russell Street, West Lafayette, IN 47907, USA
}

Correspondence should be addressed to Ermson Z. Nyakatawa, ermson.nyakatawa@aamu.edu

Received 9 February 2011; Revised 19 May 2011; Accepted 25 June 2011

Academic Editor: Ryusuke Hatano

Copyright (C) 2011 Ermson Z. Nyakatawa et al. This is an open access article distributed under the Creative Commons Attribution License, which permits unrestricted use, distribution, and reproduction in any medium, provided the original work is properly cited.

\begin{abstract}
Land application of poultry litter (PL) presents an opportunity to improve soil productivity and disposal of poultry waste. We investigated methane $\left(\mathrm{CH}_{4}\right)$ and nitrous oxide $\left(\mathrm{N}_{2} \mathrm{O}\right)$ emissions from agricultural soil receiving PL and ammonium nitrate $(\mathrm{AN})$ fertilizers using surface (SA), soil incorporation (SI), and subsurface band (BA) application methods in conventional (CT) and notillage (NT) systems on a Decatur silt loam soil in North Alabama. Plots under CT and NT were sinks of $\mathrm{CH}_{4}$ in spring, summer, and fall. In winter, the plots had net emissions of 3.32 and $4.24 \mathrm{~g} \mathrm{CH}_{4} \mathrm{ha}^{-1}$ day $^{-1}$ in CT and NT systems, respectively. Plots which received $\mathrm{AN}$ were net emitters of $\mathrm{CH}_{4}$ and $\mathrm{N}_{2} \mathrm{O}$, whereas plots which received PL were net sinks of $\mathrm{CH}_{4}$. Plots which received PL using SA or SI methods were net emitters of $\mathrm{N}_{2} \mathrm{O}$, whereas under PL using BA application, the plots were net sinks of $\mathrm{N}_{2} \mathrm{O}$. Our study indicates that using subsurface band application of PL was the most promising environmentally sustainable poultry waste application method for reducing $\mathrm{CH}_{4}$ and $\mathrm{N}_{2} \mathrm{O}$ emissions from agricultural soil in NT and CT corn production systems on the Decatur soil in north Alabama.
\end{abstract}

\section{Introduction}

The presence of the poultry industry in close proximity to row crop farming systems in north-eastern and north-central Alabama presents an opportunity to economically improve crop yields and soil quality through land application of the carbon and nitrogen-rich poultry litter (PL). Poultry litter is an organic fertilizer which is a valuable source of plant nutrients and an excellent soil amendment for improving soil quality and productivity. In addition to exploiting its economic benefits as a fertilizer, application of poultry litter to agricultural soils in conservation tillage systems is a recommended method for disposing of the large quantities of litter generated in the poultry industry of the southeastern USA [1-3].

The increasing size and concentration of animal production units has given rise to concerns about air emissions on the earth's atmosphere at local and global scales [4]. Methane $\left(\mathrm{CH}_{4}\right)$ and nitrous oxide $\left(\mathrm{N}_{2} \mathrm{O}\right)$ are major agricultural greenhouse gases with greater global warming potential than carbon dioxide $\left(\mathrm{CO}_{2}\right)$ and can significantly contribute to climate change. According to the Intergovernmental Panel on Climatic Change, $\mathrm{CH}_{4}$ is about 20 to 21 times more effective as a greenhouse gas than $\mathrm{CO}_{2}$, while $\mathrm{N}_{2} \mathrm{O}$ has a direct global warming potential 170 to 290 times that of $\mathrm{CO}_{2}$ [5].

Agricultural soil is a natural source of $\mathrm{CH}_{4}$ and $\mathrm{N}_{2} \mathrm{O}$ greenhouse gases. Soil microbial activity is the primary factor leading to the production of biogenic gases such as $\mathrm{CH}_{4}$ and $\mathrm{N}_{2} \mathrm{O}[6,7]$. Soil $\mathrm{CH}_{4}$ emission is a product of $\mathrm{CH}_{4}$ oxidation and methanogenesis [8]. According to Conrad [9], the two microbial processes of $\mathrm{CH}_{4}$ oxidation and methanogenesis can occur simultaneously, even in arable terrestrial ecosystems. The three groups of organisms which 
take part in the microbial processes leading to soil $\mathrm{CH}_{4}$ fluxes are methanotrophic bacteria, ammonia oxidizing bacteria, and methanogenic bacteria [10]. The majority of soil $\mathrm{N}_{2} \mathrm{O}$ emissions come from $\mathrm{N}_{2} \mathrm{O}$ produced as an intermediate during nitrification and denitrification processes [11]. Therefore, soil and animal waste management strategies which can reduce or prohibit $\mathrm{CH}_{4}$ formation and inhibit soil denitrification process can minimize emissions of $\mathrm{CH}_{4}$ and $\mathrm{N}_{2} \mathrm{O}$ greenhouse gases from agricultural soils.

Use of organic and inorganic fertilizers for crop production has been widely documented to increase emissions of agricultural greenhouse gases [12-17]. Manures from poultry and livestock contain proteins, amino acids, and carbohydrates, which provide a source of energy for bacteria, which, upon decomposition, can release greenhouse gases such as $\mathrm{CO}_{2}$ and $\mathrm{CH}_{4}$, in addition to odor causing gases such as ammonia $\left(\mathrm{NH}_{3}\right)$ and hydrogen sulfide $\left(\mathrm{H}_{2} \mathrm{~S}\right)$. Odors, gases, and particulate matter from use of animal manures in agriculture are a cause of concern from social, environmental quality, and human health points of view. Land application of animal waste has been reported to increase soil emissions of greenhouse gases [18, 19]. Therefore, if not properly managed, soil-applied PL can potentially contribute to the enrichment of the atmosphere with greenhouse gases such as $\mathrm{CH}_{4}$ and $\mathrm{N}_{2} \mathrm{O}$.

Due to their relatively long chemical lifetime and stability, $\mathrm{CH}_{4}$ and $\mathrm{N}_{2} \mathrm{O}$ can be transported into the stratosphere where they contribute to destruction of ozone [16, 20]. Consequently, while land application of PL presents an opportunity for disposing of the large quantities of poultry waste, there is a need to develop soil, crop, and animal utilization strategies to minimize emissions of greenhouse gases from agricultural soil which can make the disposal of poultry litter through land application environmentally sustainable. In areas of intensive animal production with limited disposal areas such as the intensive poultry producing region of north Alabama, repeated applications of manure on the same piece of land are common. This not only increases the risk of soil and water pollution from excess nutrients such as N [21] and $\mathrm{P}$ but also can potentially lead to increased soil emissions of agricultural greenhouse gases.

In addition to being a source of soil $\mathrm{CH}_{4}$, agricultural soils can be effective sinks of atmospheric $\mathrm{CH}_{4}$, which can have a significantly impact on net ecosystem $\mathrm{CH}_{4}$ balances. Agricultural practices such as tillage and fertilizer management practices can affect the soil's ability to act as a sink of atmospheric $\mathrm{CH}_{4}$ [22]. Studies on greenhouse gas emissions from animal waste-treated soils have largely dealt with dairy cattle or liquid swine manure in the Midwestern USA and elsewhere. Information regarding greenhouse gas emissions from soils treated with poultry waste in the Southeastern USA is lacking. Studies to document the impact of soil and fertilizer management strategies on current and future inventories of soil greenhouse gas emissions, taking into account the various types of animal wastes and different agroecological regions, are needed. The objectives of this study were to investigate emissions of $\mathrm{CH}_{4}$ and $\mathrm{N}_{2} \mathrm{O}$ from agricultural soil receiving PL and ammonium nitrate (AN) fertilizers using surface, soil incorporation, and subsurface band application methods in conventional tillage (CT) and notillage (NT) systems in a corn (Zea mays, L.) production system.

\section{Materials and Methods}

2.1. Study Location. The study was conducted at the Winfred Thomas Agricultural Experiment Station, Hazel Green, Alabama (latitude $34^{\circ} 89^{\prime} \mathrm{N}$ and longitude $86^{\circ} 56^{\prime} \mathrm{W}$ ), which is strategically situated in a major row crop and poultry producing area in the Tennessee Valley region of north Alabama. The soil at the study site is a Decatur silt loam (fine, kaolinitic, thermic Rhodic Paleudult). We chose a fallow field under tall fescue grass (Festuca arundinacea, L.) which had not received organic or inorganic fertilizers for over 10 years to eliminate the effect of previously added soil nutrients on $\mathrm{CH}_{4}$ and $\mathrm{N}_{2} \mathrm{O}$ exchanges in the study plots. Baseline soil properties in the plots prior to treatment establishment are presented in Table 1.

2.2. Treatments and Experimental Design. Treatment factors consisted of two tillage systems: conventional tillage (CT) and no-tillage (NT); two N sources: poultry litter (PL) and ammonium nitrate (AN); and three fertilizer application methods: surface application (SA), soil incorporation (SI), and subsurface band application (BA) (poultry litter only). The fertilizers were applied at a rate of $150 \mathrm{~kg} \mathrm{~N} \mathrm{ha}^{-1}$ to represent the recommended rate for corn on the Decatur soil type. In addition, a tall fescue grass fallow and a $0 \mathrm{~kg} \mathrm{Nha}^{-1}$ treatment were used to determine background $\mathrm{CH}_{4}$ and $\mathrm{N}_{2} \mathrm{O}$ greenhouse gas emissions in plots without tillage and fertilizer application.

The plots were arranged in a randomized complete block design with four replications. However, gas sampling was done in the first three replications for practical and technical feasibility reasons, such as sampling time and laboratory instrumentation capabilities. Gross plot size was $8 \mathrm{~m} \times 8 \mathrm{~m}$. The replications were separated from each other by a fescue grass strip $8 \mathrm{~m}$ wide, while individual plots within a replication were separated from each other by a $2 \mathrm{~m}$ wide tall fescue grass strip to hydrologically isolate different treatments from each other and prevent nutrient spill over from plots receiving fertilizer treatments into adjacent plots.

Conventional tillage included fall chisel plowing using a field cultivator and spring disking to prepare the seedbed before corn planting as per local farmer's practice. No-tillage treatment involved planting a wheat (Triticum aestivum L.) cover crop in the fall of 2007, 2008, and 2009 and killing the cover crop with glyphosate herbicide prior to planting corn in the standing residue in the spring of each year. The wheat cover crop did not receive any fertilizer to encourage it to efficiently "scavenge" residual soil nutrients and incorporate them as above ground biomass during the winter season to reduce runoff and leaching losses of nutrients. The amount of poultry litter to supply $150 \mathrm{~kg} \mathrm{~N} \mathrm{ha}^{-1}$ was calculated based on the $\mathrm{N}$ content of poultry litter, which was determined using the LECO TruSpec CN analyzer (LECO Corporation, St. Joseph MI). 
TABLE 1: Baseline soil properties at the study site prior to establishing treatments, Hazel Green, Alabama.

\begin{tabular}{|c|c|c|c|c|c|}
\hline Soil depth $(\mathrm{cm})$ & $\mathrm{pH}$ & $\begin{array}{l}\mathrm{NH}_{4}-\mathrm{N} \\
\mathrm{mg} \mathrm{kg}^{-1}\end{array}$ & $\begin{array}{l}\mathrm{NO}_{3}-\mathrm{N} \\
\mathrm{mg} \mathrm{kg}^{-1}\end{array}$ & $\begin{array}{c}\mathrm{PO}_{4}-\mathrm{P} \\
\mathrm{mg} \mathrm{kg}^{-1}\end{array}$ & $\begin{array}{r}\text { Total C } \\
\left(\mathrm{g} \mathrm{kg}^{-1}\right)\end{array}$ \\
\hline $0-5$ & 6.21 & 9.22 & 15.26 & 6.15 & 14.22 \\
\hline $5-10$ & 6.19 & 8.15 & 23.12 & 5.08 & 8.53 \\
\hline $10-20$ & 6.31 & 5.64 & 15.18 & 6.10 & 7.04 \\
\hline $20-30$ & 6.36 & 6.15 & 12.71 & 4.46 & 5.09 \\
\hline $30-60$ & 6.26 & 5.81 & 8.16 & 2.17 & 4.03 \\
\hline $60-120$ & 6.03 & 4.65 & 5.40 & 1.67 & 3.70 \\
\hline S.E. & 0.2 & 3.7 & 8.8 & 4.4 & 0.3 \\
\hline
\end{tabular}

TABLE 2: Tillage and fertilizer treatments used in the $\mathrm{CH}_{4}$ and $\mathrm{N}_{2} \mathrm{O}$ greenhouse gas flux study, Hazel Green, Alabama.

\begin{tabular}{|c|c|c|c|c|}
\hline Treatment code & Tillage system & $\mathrm{N}$ source & $\mathrm{N}$ rate $\left(\mathrm{kg} \mathrm{Nha}^{-1}\right)$ & $\mathrm{N}$ application method \\
\hline CT-0N & Conventional (CT) & None & 0 & $\mathrm{~N} / \mathrm{A}$ \\
\hline CT-150AN-SA & Conventional (CT) & $\mathrm{AN}^{\dagger}$ & 150 & Surface application (SA) \\
\hline CT-150AN-SI & Conventional (CT) & $\mathrm{AN}$ & 150 & Soil incorporation (SI) \\
\hline CT-150PL-SA & Conventional (CT) & PL & 150 & Surface application (SA) \\
\hline CT-150PL-BA & Conventional (CT) & PL & 150 & Subsurface band application (BA) \\
\hline CT-150PL-SI & Conventional (CT) & PL & 150 & Soil incorporation $(\mathrm{SI})$ \\
\hline NT-0N & No-till (NT) & None & 0 & N/A \\
\hline NT-150AN-SA & No-till (NT) & AN & 150 & Surface application (SA) \\
\hline NT-150PL-SA & No-till (NT) & PL & 150 & Surface application (SA) \\
\hline NT-150PL-BA & No-till (NT) & PL & 150 & Subsurface band application (BA) \\
\hline GF-0N & Grass Fallow (GF) & None & 0 & N/A \\
\hline
\end{tabular}

${ }^{\dagger}$ AN: ammonium nitrate; PL: poultry litter.

Surface application involved broadcasting weighed quantities of PL or AN fertilizers to supply $150 \mathrm{~kg} \mathrm{Nha}^{-1}$ on the soil surface in both CT and NT systems. Soil incorporation application method involved broadcasting weighed quantities of PL or AN fertilizers to supply $150 \mathrm{~kg} \mathrm{Nha}^{-1}$ on the soil surface followed by soil incorporation using a rototiller in CT system.

Subsurface band application was achieved by applying known quantities of PL to supply $150 \mathrm{~kg} \mathrm{Nha}^{-1}$ in a narrow band, $4.4 \mathrm{~cm}$ wide to a depth of about $7 \mathrm{~cm}$ and covering it with soil using a prototype implement for subsurface band application of PL developed at the USDA-ARS National Soil Dynamics Laboratory, Auburn AL [23]. The distance between the PL bands was $97 \mathrm{~cm}$. Soil incorporation of fertilizer was not used in the NT system, while subsurface banding was not used with AN fertilizer, resulting in an incomplete factorial set of treatments (Table 2). Field operations for fertilizer application and fertilizer incorporation were done on April 23, 2008 and April 24, 2009. Corn was planted in the plots at $97 \mathrm{~cm}$ row spacing on April 24 in spring of 2008 and 2009.

2.3. Gas Sampling and Laboratory Analyses. Soil gas samples were collected using custom-built static PVC chambers designed in accordance with the USDA-ARS GRACEnet Chamber-based Trace Gas Flux Measurement Protocol [24]. The chambers consisted of two parts: a chamber anchor base and a vented sampling chamber head. The chamber bases were made from white PVC pipe, $20 \mathrm{~cm}$ inside diameter,
$6 \mathrm{~mm}$ thick, and $15 \mathrm{~cm}$ long. The chamber bases were driven $10 \mathrm{~cm}$ into the ground using a rectangular wooden block and a rubberized mallet, leaving a soil collar $5 \mathrm{~cm}$ above the ground. Two chamber bases were installed in each plot immediately after corn planting, one between corn rows and one within the corn row. The chamber heads were made from $10 \mathrm{~cm}$ long socket end-caps of the same white PVC pipe material which was used to make the anchor bases and are designed to fit closely over the PVC pipe chamber anchor bases. The white external surfaces were chosen to reflect sun rays to prevent temperature increase inside the chambers during gas sampling.

Three tight fitting butyl rubber corks were glued to the top of the flux chamber head. A PVC vent tube $10 \mathrm{~cm}$ long and $4.8 \mathrm{~mm}$ inside diameter was inserted into the first butyl rubber cork on top of the flux chamber head to offset pressure differences between the inside and outside of the flux chamber during measurements. A thermometer was inserted into the second butyl rubber cork to measure temperature inside the flux chamber during measurements. The third butyl rubber cork was used as a sampling port into which a syringe needle was inserted during gas sampling. In addition, a small fan driven by a $12 \mathrm{~V}$ DC electric motor was mounted on the inside wall of the flux chamber head to thoroughly mix the air inside the flux chamber during gas sampling.

The chamber anchor bases were kept open at all times except during gas sampling time. During gas sampling, the chamber anchor bases were fitted with the tight fitting vented chamber heads. Gas samples were collected into $25 \mathrm{~mL}$ 
polypropylene leak-proof syringes with a $0.72 \mathrm{~mm}$ outside diameter (22 gauge) flat-end needle. During gas sampling, the air inside the chamber was mixed by repeatedly pumping air into the syringe and expelling the air, three to five times. Gas samples were extracted at 0-, 10-, and 20-minute time intervals. Sampling was typically restricted to between $10 \mathrm{am}$ and $2 \mathrm{pm}$ to avoid large temperature fluctuations during gas collection periods. Gas sampling was done once prior to tillage and planting operations immediately after planting in spring in 2008 and 2009. Post-planting gas sampling was done at a frequency of at least once every month during spring, summer, fall, and winter seasons in each year.

Immediately after extraction, the $25 \mathrm{~mL}$ gas samples were transferred to $20 \mathrm{~mL}$ pre-evacuated vials sealed with butyl rubber septa (Varian Inc, Palo Alto, CA), which over-pressurized the system to ensure that in case of any leakage, gas sample movement will only be out of the vials and not into the vials. The vials containing the soil gas samples were put into Ziploc bags and taken to the laboratory for greenhouse gas analyses. The gas samples were analyzed using a Varian CP-3800 gas chromatograph (Varian Inc, Palo Alto, CA) equipped with a ${ }^{65} \mathrm{Ni}$ electron capture detector (ECD) and a flame ion detector (FID) for $\mathrm{N}_{2} \mathrm{O}$ and $\mathrm{CH}_{4}$ concentration measurements, respectively.

2.4. Surface Flux Calculation. Surface fluxes of $\mathrm{CH}_{4}$ and $\mathrm{N}_{2} \mathrm{O}$ were calculated using the following equation by Hutchinson and Livingston [25]:

$$
f_{0}=\frac{\Delta C}{\Delta T} \times \frac{V}{A} \times \frac{M}{V_{\mathrm{mol}}},
$$

where $f_{o}$ is the flux rate of soil $\mathrm{CH}_{4}$ or $\mathrm{N}_{2} \mathrm{O}$ gas $\left(\mu \mathrm{g} \mathrm{m}^{-2} \mathrm{~min}^{-1}\right), \Delta C / \Delta T$ is the rate of change of gas concentration inside the measuring chamber $\left(\mu \mathrm{g} \mathrm{min}^{-1}\right), V$ is the head-space volume of the measuring chamber $\left(\mathrm{m}^{3}\right), A$ is the surface area of the measuring chamber $\left(\mathrm{m}^{2}\right), M$ is the molecular weight of the gas ( 16 and $44 \mathrm{~g} \mathrm{~mol}^{-1}$ for $\mathrm{CH}_{4}$ and $\mathrm{N}_{2} \mathrm{O}$ resp.), and $V_{\text {mol }}$ is the molar volume of gas $\left(\mathrm{m}^{3} \mathrm{~mol}^{-1}\right)$. In each plot, flux values from the flux chamber within the crop row and the flux chamber between the crop row were averaged to represent the flux value for each plot.

In plots with the subsurface band PL application treatment, the effective flux for the plot was calculated taking into account that the PL band covered only a narrow $(4.4 \mathrm{~cm}$ wide) strip within the chamber. The adjustment for the effective soil gas flux from the PL band was done using the equation by Way et al. [26]:

$$
F_{E, B}=\frac{\left(F_{B} W_{B}+\mathrm{F}_{\mathrm{FC}, \mathrm{Ctrl}}\left(S_{B}-W_{B}\right)\right)}{S_{B}},
$$

where $F_{E, B}$ is the effective soil gas flux from a banded plot $\left(\mu \mathrm{g} \mathrm{m}^{-2} \mathrm{~min}^{-1}\right) ; F_{B}$ is the soil gas flux from the band alone $\left(\mu \mathrm{g} \mathrm{m}^{-2} \mathrm{~min}^{-1}\right) ; W_{B}$ is the width of the PL band $(m)$; $F_{\mathrm{FC}, \mathrm{Ctrl}}$ is the soil gas flux from the chamber without a PL band $\left(\mu \mathrm{g} \mathrm{m}^{-2} \mathrm{~min}^{-1}\right)$; $S_{B}$ is the center-to-center band spacing $(m)$. This adjustment was done to account for the fact that greenhouse gas fluxes per unit area directly above the PL band are different from fluxes from the area inside the same

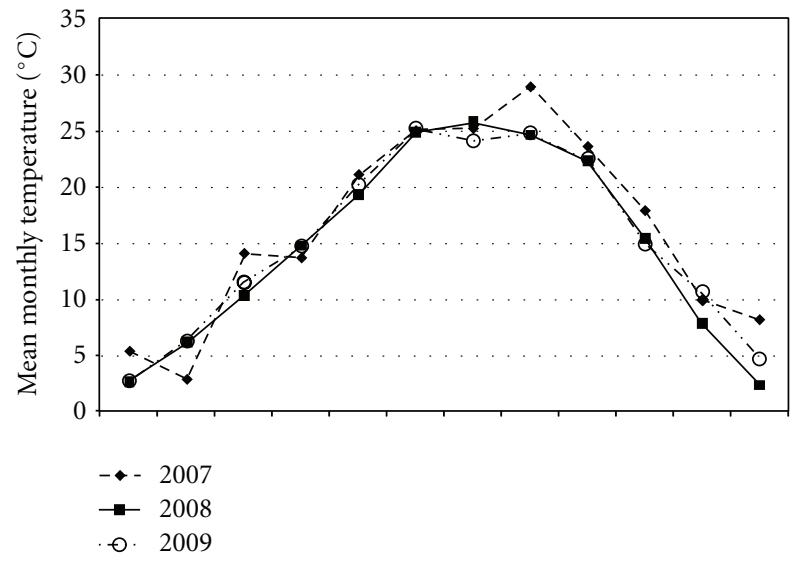

(a)

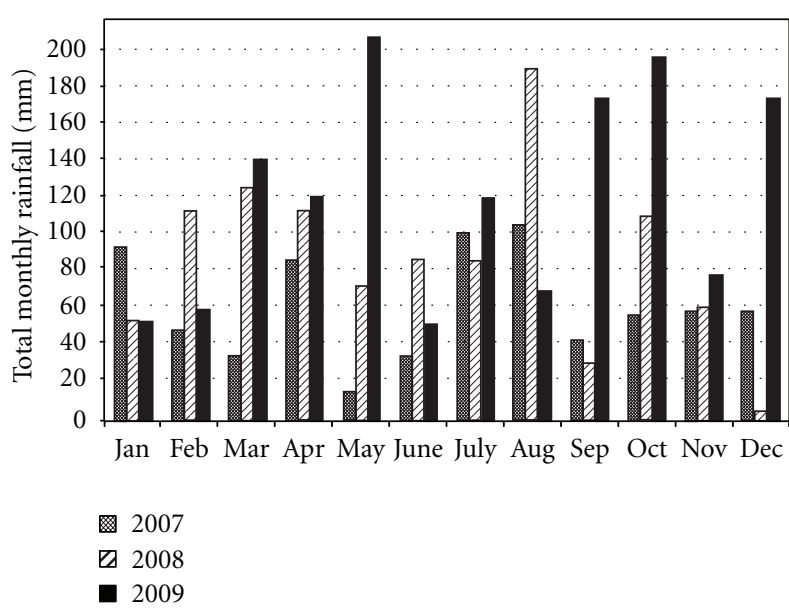

(b)

Figure 1: Monthly rainfall totals and mean monthly temperatures at study site, Hazel Green, Alabama.

chamber where there is no band. It also accounts for the fact that the PL bands do not actually cover the whole plot area.

2.5. Ancillary Data. During gas sampling, soil temperature in the top $5-10 \mathrm{~cm}$ of the soil was measured using Mannix digital soil thermometers permanently installed in the plots. Daily weather data were recorded using an automatic weather station at the study site. Mean monthly temperature and total monthly rainfall at the study site during the study period are presented in Figure 1.

2.6. Statistical Analyses. The general linear models analysis of variance (ANOVA) procedure [27] was used for analyzing the data collected in this study using SAS, ver. 9.03 software [28].

The least significant difference test was used to compare treatment mean differences for the measured variables. Pearson correlation analysis was used to determine relationships between $\mathrm{CH}_{4}$ and $\mathrm{N}_{2} \mathrm{O}$ greenhouse gas fluxes and other measured variables such as soil temperature. 
TABLE 3: Soil methane fluxes as influenced by tillage systems and ammonium nitrate (AN) and poultry litter (PL) N fertilizers using surface (SA), soil incorporation (SI), and subsurface band (BA) application methods in spring, summer, fall, and winter seasons, Hazel Green, Alabama.

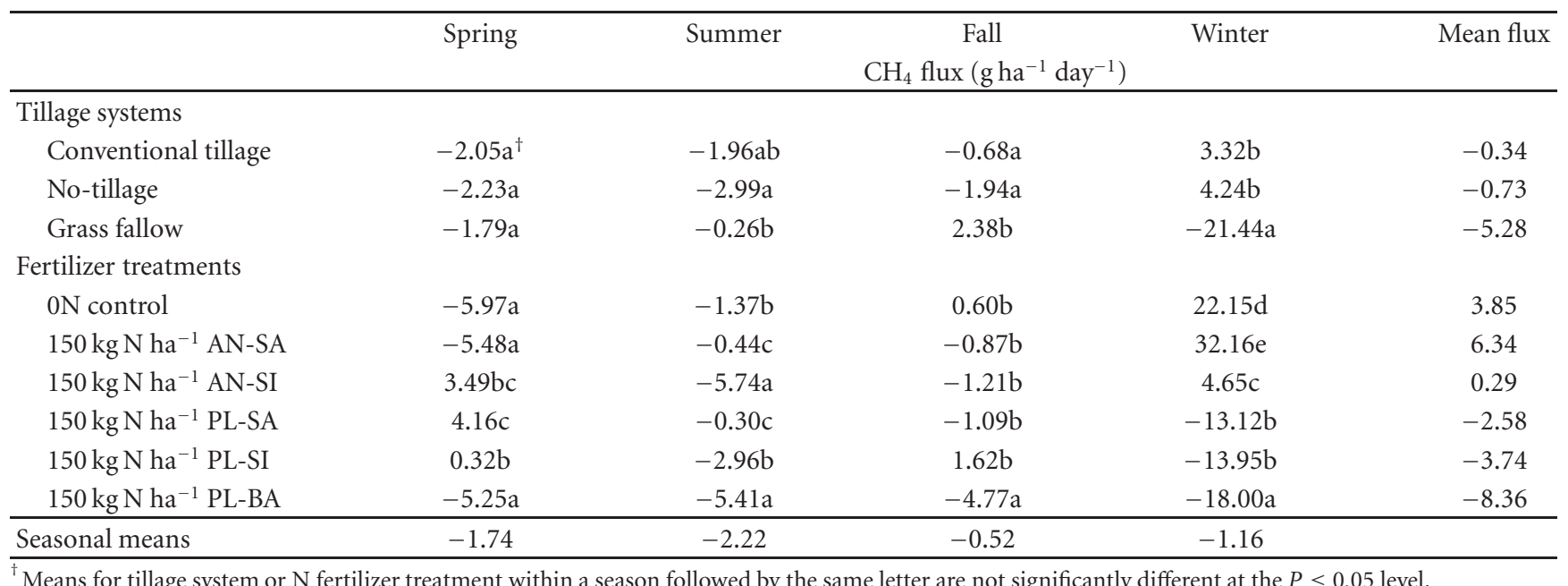

${ }^{\dagger}$ Means for tillage system or $\mathrm{N}$ fertilizer treatment within a season followed by the same letter are not significantly different at the $P \leq 0.05$ level.

\section{Results and Discussion}

3.1. Methane $\left(\mathrm{CH}_{4}\right)$ Flux. The trend in soil $\mathrm{CH}_{4}$ fluxes for the 11 treatments at different sampling periods during the two-year study period shows variations in $\mathrm{CH}_{4}$ fluxes within and among treatments at different sampling periods (Figure 2). Means of soil $\mathrm{CH}_{4}$ fluxes for tillage and $\mathrm{N}$ fertilizer treatments in spring, summer, fall, and winter during the study period are given in Table 3. Soil $\mathrm{CH}_{4}$ fluxes in the plots under CT and NT systems were negative in spring, summer, and fall, whereas in winter, positive soil $\mathrm{CH}_{4}$ fluxes of 3.32 and $4.24 \mathrm{~g} \mathrm{CH}_{4} \mathrm{ha}^{-1}$ day ${ }^{-1}$ were observed in plots under conventional and NT systems, respectively (Table 3 ).

A positive gas flux implies that the measured gas was moving from the soil to the atmosphere during the time of measurement. This happens when the value of the term " $\Delta C / \Delta T$ " in the equation $f o=\Delta C / \Delta T \times V / A \times M / V_{\mathrm{mol}}$ is positive; that is, the gas concentration inside the sampling chamber during the measuring time was increasing with time. A negative gas flux is the reverse of the above, which implies that the gas was moving from the atmosphere into the soil during the time of measurement; that is, the concentration of gas inside the chamber was decreasing with time during the time of measurement. In that case, the term " $\Delta C / \Delta T$ " in the equation $f o=\Delta C / \Delta T \times V / A \times M / V_{\text {mol }}$ is negative.

The above results show that plots under CT and NT systems were sinks of atmospheric $\mathrm{CH}_{4}$ in spring, summer, and fall. However, the same plots were emitters of soil $\mathrm{CH}_{4}$ in winter. Plots under the grass fallow system were sinks of atmospheric $\mathrm{CH}_{4}$ in spring, summer, and winter, whereas in fall, the plots were emitters of $\mathrm{CH}_{4}$. The seasonal variation in soil $\mathrm{CH}_{4}$ fluxes among tillage systems was attributed to changes in soil environmental conditions. Soil $\mathrm{CH}_{4}$ fluxes were significantly positively correlated $(P<0.03)$ to soil moisture content and negatively correlated to soil temperature $(P<0.02)$ at sampling time. In spring and summer, the soil acted as a sink of atmospheric $\mathrm{CH}_{4}$ in CT and NT systems which had lower soil moisture content, and less so in grass fallow plots which had higher soil moisture content. In winter when CT and NT plots had relatively higher soil moisture content, the plots were net emitters of $\mathrm{CH}_{4}$ (Table 3).

According to Linn and Doran [29], the percentage of soil pore space filled with water, as determined by water content, and total porosity appears to be closely related to soil microbial activity under different tillage regimes. The fact that even for the same soil type, soil microbial activity under CT, NT, and grass fallow systems can vary due to different soil moisture content can explain the differences in soil $\mathrm{CH}_{4}$ fluxes between different tillage systems. A greater pore continuity and the presence of ecological niches for methanotrophic bacteria in NT systems lead to increased $\mathrm{CH}_{4}$ uptake compared to CT systems.

Plots which received $\mathrm{N}$ fertilizer in the form of inorganic AN fertilizer using surface application method (AN-SA) or PL using the subsurface band application method (PLBA) and the control $\left(0 \mathrm{~kg} \mathrm{Nha}^{-1}\right)$ plots had negative soil $\mathrm{CH}_{4}$ fluxes of about $-5.00 \mathrm{~g} \mathrm{CH}_{4} \mathrm{ha}^{-1}$ day $^{-1}$ in spring (Table 3). Plots which received $150 \mathrm{~kg} \mathrm{Nha}^{-1}$ AN using soil incorporation application method (AN-SI), PL using surface application method (PL-SA), and PL using soil incorporation method (PL-SI) had mean soil $\mathrm{CH}_{4}$ emissions ranging from 0.32 to $4.16 \mathrm{~g} \mathrm{CH}_{4} \mathrm{ha}^{-1}$ day $^{-1}$ in spring. In summer and fall, soil $\mathrm{CH}_{4}$ fluxes in the plots were generally negative, irrespective of $\mathrm{N}$ fertilizer treatment. However, in winter, plots which received AN-SA, AN-SI, and the control plots had mean soil $\mathrm{CH}_{4}$ emissions ranging from 4.65 to $32.16 \mathrm{~g} \mathrm{CH}_{4} \mathrm{ha}^{-1} \mathrm{day}^{-1}$, while plots which received PL-SA, $\mathrm{PL}-\mathrm{SI}$, and PL-BA had negative soil $\mathrm{CH}_{4}$ fluxes ranging from -18.00 to $-13.12 \mathrm{~g} \mathrm{CH}_{4} \mathrm{ha}^{-1}$ day $^{-1}$ (Table 3). Seasonal soil $\mathrm{CH}_{4}$ fluxes averaged over tillage and fertilizer treatments show that the plots were sinks of $\mathrm{CH}_{4}$ in all seasons.

The data for soil $\mathrm{CH}_{4}$ fluxes at various sampling periods during the study period as shown in Figure 2 is useful in 


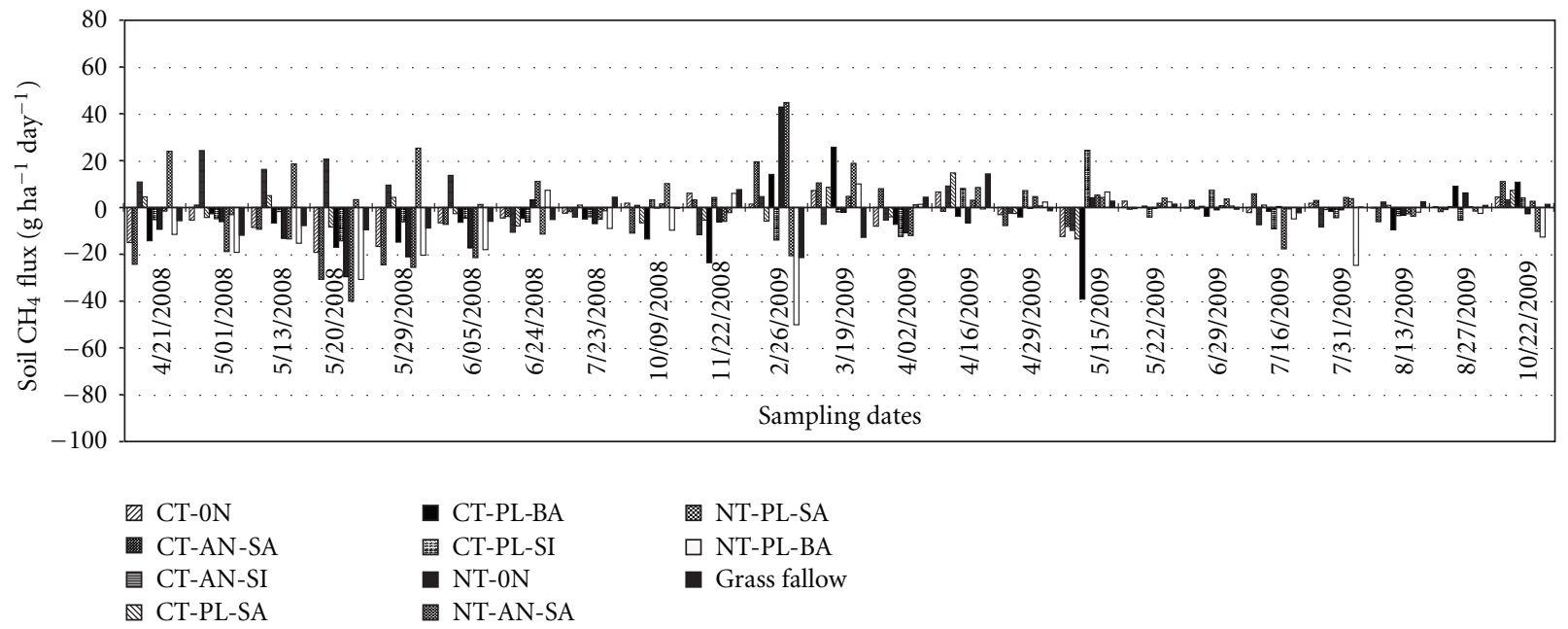

Figure 2: Soil $\mathrm{CH}_{4}$ fluxes in corn plots receiving ammonium nitrate (AN) and poultry litter (PL) N fertilizers using surface (SA), soil incorporation (SI), and subsurface band (BA) application methods in conventional tillage (CT) and no-tillage (NT), systems, Hazel Green, Alabama.

showing trends in gas fluxes over time. The different soil management practices represented by tillage and fertilizer treatments show a pattern whereby the soil fluctuated between being a source and a sink of $\mathrm{CH}_{4}$. Therefore, mean $\mathrm{CH}_{4}$ flux data over time is more important in quantifying the net effect of different crop and soil management strategies and hence in making assessments of agricultural contributions of greenhouse gases to the environment. Mean $\mathrm{CH}_{4}$ fluxes in each tillage system averaged over seasons during the study period were $-0.34,-0.73$, and $-5.28 \mathrm{~g} \mathrm{CH}_{4} \mathrm{ha}^{-1}$ day $^{-1}$ in plots under CT, NT, and grass fallow plots, respectively (Table 3 ).

These results show that all the plots used in the study were net sinks of atmospheric $\mathrm{CH}_{4}$ irrespective of tillage system. This is consistent with reports by other researchers, that in general, upland soils are $\mathrm{CH}_{4}$ sinks [30]. In agreement with our findings, Johnson et al. [31] also found no significant differences in soil $\mathrm{CH}_{4}$ fluxes between $\mathrm{CT}$ and NT. However, Alluvione et al. [32] found higher $\mathrm{CH}_{4}$ emissions in NT (20.2 $\left.\mathrm{g} \mathrm{CH}_{4} \mathrm{ha}^{-1}\right)$ compared to CT (1.2 $\left.\mathrm{g} \mathrm{CH}_{4} \mathrm{ha}^{-1}\right)$ on a clay loam soil in northeastern Colorado. Since upland terrestrial soils are generally $\mathrm{CH}_{4}$ sinks, they can play a significant role in mitigating the enrichment of the atmosphere with this greenhouse gas. In our study, the grass fallow plots were the highest sinks of atmospheric $\mathrm{CH}_{4}$. Several other studies have also shown that grassland soils are usually sinks of $\mathrm{CH}_{4}$ [33-37].

Mean $\mathrm{CH}_{4}$ fluxes in each $\mathrm{N}$ fertilizer treatment averaged over seasons during the study period show that plots which received inorganic AN fertilizer and the control plots were net emitters of soil $\mathrm{CH}_{4}$ irrespective of application method, with fluxes ranging from 0.29 to $6.34 \mathrm{~g} \mathrm{CH}_{4} \mathrm{ha}^{-1} \mathrm{day}^{-1}$, whereas plots which received $\mathrm{N}$ fertilizer in the form of PL were net sinks of atmospheric $\mathrm{CH}_{4}$ irrespective of application method, with fluxes ranging from -8.36 to $-2.58 \mathrm{~g}$ $\mathrm{CH}_{4}$ ha $^{-1}$ day $^{-1}$ (Table 3). Mean $\mathrm{CH}_{4}$ fluxes averaged over all the treatments during the study show that the plots were a net sink of $\mathrm{CH}_{4}$ with a flux of $-5.64 \mathrm{~g} \mathrm{CH}_{4} \mathrm{ha}^{-1} \mathrm{day}^{-1}$.
In soils, $\mathrm{CH}_{4}$ is produced from anaerobic decomposition of organic material by methanogenic bacteria which consume soil $\mathrm{CO}_{2}$ and convert it to $\mathrm{CH}_{4}$ gas. According to R.S. Hanson and T.E. Hanson [38], oxidation of $\mathrm{CH}_{4}$ by methanotrophic bacteria is the only known net biological sink for atmospheric $\mathrm{CH}_{4}$ and terrestrial emissions. Subsurface band application of PL can cause an increased rate of soil microbial activity under warm temperatures and moist soil conditions in aerated soils in spring and summer. Under favorable soil conditions, methanotrophic soil bacteria consume $\mathrm{CH}_{4}$ gas in the soil which favors soil $\mathrm{CH}_{4}$ uptake. Nitrogen fertilization has been demonstrated to stimulate certain soil methanotrophs, while inhibiting other methanotrophs [39]. Therefore, increased microbial activity can result in increased rate of $\mathrm{CH}_{4}$ consumption by methanotrophic bacteria which may have a net effect of causing the soil to be a sink of atmospheric $\mathrm{CH}_{4}$.

According to Bédard and Knowles [40], oxidation of $\mathrm{CH}_{4}$ in soils can also be carried out by nitrifying bacteria, which have an affinity for $\mathrm{CH}_{4}$ similar to that of the common methanotrophs. This may suggest that conditions favorable for nitrification bacteria, such as the supply of $\mathrm{C}$ and $\mathrm{N}$ rich organic matter from PL, can actually promote the net movement of atmospheric $\mathrm{CH}_{4}$ into the soil when the PL is concentrated in a band. On the other hand, inorganic $\mathrm{N}$ fertilization has been reported to inhibit $\mathrm{CH}_{4}$ consumption activity in arable soils [41-44]. This may explain why plots which received $150 \mathrm{~kg} \mathrm{~N} \mathrm{ha}^{-1}$ in the form of inorganic AN fertilizer had cumulative $\mathrm{CH}_{4}$ emissions whereas plots which received $150 \mathrm{~kg} \mathrm{~N} \mathrm{ha}^{-1}$ in form of PL were net sinks of $\mathrm{CH}_{4}$ (Table 2). In a tropical rice field alluvial soil, Nayak et al. [45] reported that organic and mineral fertilizer stimulated $\mathrm{CH}_{4}$ oxidation whereas application of both organic and mineral fertilizer inhibited $\mathrm{CH}_{4}$ oxidation probably due to $\mathrm{N}$ immobilization. In contrast to most findings, HernandezRamirez et al. [46] reported that soils which received manure in a continuous corn cropping system were net seasonal $\mathrm{CH}_{4}$ emitters, whereas similar plots receiving inorganic urea 
nitrogen fertilizer were sinks of $\mathrm{CH}_{4}$ in the eastern U.S. Corn Belt.

3.2. Nitrous Oxide $\left(\mathrm{N}_{2} \mathrm{O}\right)$ Flux. As with soil $\mathrm{CH}_{4}$ flux data, there was a significant variation in soil $\mathrm{N}_{2} \mathrm{O}$ fluxes within and among tillage and fertilizer treatments (Figure 3).

There was a significant seasonal variation in soil $\mathrm{N}_{2} \mathrm{O}$ fluxes among tillage and $\mathrm{N}$ fertilizer treatments (Table 4). There was no significant difference in soil $\mathrm{N}_{2} \mathrm{O}$ fluxes between CT and NT systems which had mean $\mathrm{N}_{2} \mathrm{O}$ fluxes of 20.99 and $23.70 \mathrm{~g} \mathrm{~N}_{2} \mathrm{O} \mathrm{ha}{ }^{-1}$ day $^{-1}$, respectively, in spring. However, the mean soil $\mathrm{N}_{2} \mathrm{O}$ flux of $50.45 \mathrm{~g} \mathrm{~N}_{2} \mathrm{O} \mathrm{ha}^{-1}$ day $^{-1}$ in grass fallow plots was about twice that for plots under CT and NT systems in spring (Table 4). Johnson et al. [31] reported high $\mathrm{N}_{2} \mathrm{O}$ fluxes in spring but found no significant differences in annual cumulative $\mathrm{N}_{2} \mathrm{O}$ fluxes between $\mathrm{CT}$ and NT systems. In Minnesota, Venterea et al. [47] found no significant differences in $\mathrm{N}_{2} \mathrm{O}$ emissions between CT and NT systems when using urea ammonium nitrate fertilizer in corn plots.

A mean soil $\mathrm{N}_{2} \mathrm{O}$ emission of $14.50 \mathrm{~g} \mathrm{~N}_{2} \mathrm{O} \mathrm{ha}^{-1}$ day $^{-1}$ was observed in the NT system in summer, whereas plots under $\mathrm{CT}$ and grass fallow systems were sinks of $\mathrm{N}_{2} \mathrm{O}$ with fluxes of -37.60 and $-71.80 \mathrm{~g} \mathrm{~N}_{2} \mathrm{O} \mathrm{ha}^{-1}$ day $^{-1}$, respectively. In fall, plots under CT and NT systems had soil $\mathrm{N}_{2} \mathrm{O}$ fluxes of -19.20 and $-106.30 \mathrm{~g} \mathrm{~N}_{2} \mathrm{O} \mathrm{ha}^{-1}$ day $^{-1}$, respectively, whereas the grass fallow plots had a mean soil $\mathrm{N}_{2} \mathrm{O}$ emission of $122.0 \mathrm{~g} \mathrm{~N}_{2} \mathrm{O} \mathrm{ha}^{-1} \mathrm{day}^{-1}$ (Table 4). In winter, plots under CT system had a mean soil $\mathrm{N}_{2} \mathrm{O}$ emission of $45.05 \mathrm{~g} \mathrm{~N}_{2} \mathrm{O}$ $\mathrm{ha}^{-1}$ day $^{-1}$, whereas NT and grass fallow plots were sinks of $\mathrm{N}_{2} \mathrm{O}$ with flux rates of -19.27 and $-14.95 \mathrm{~g} \mathrm{~N}_{2} \mathrm{O} \mathrm{ha}^{-1}$ day $^{-1}$, respectively.

Seasonal variation in soil $\mathrm{N}_{2} \mathrm{O}$ fluxes has been reported by other researchers. Our results are in agreement with the findings of Jacinthe and Dick [20] who reported that seasonal $\mathrm{N}_{2} \mathrm{O} \mathrm{N}$ losses from chisel-tilled plots were generally significantly higher than those from NT plots. Jacinthe and Dick [20] also reported average daily $\mathrm{N}_{2} \mathrm{O}$ emissions ranging from 0.1 to $326 \mathrm{~g} \mathrm{~N}_{2} \mathrm{O} \mathrm{ha} \mathrm{hay}^{-1}$ in a corn/soybean (Glycine max L.)/wheat (Triticum aestivum L.)/hairy vetch (Vicia villosa Roth) rotation study, with seasonal $\mathrm{N}_{2} \mathrm{O} N$ losses which were highest in continuous corn plots and lowest in soybean plots. Hernandez-Ramirez et al. [46] found significant seasonal variation in $\mathrm{N}_{2} \mathrm{O}$ emissions in an eastern Corn Belt soil, while Almaraz et al. [48] found higher $\mathrm{N}_{2} \mathrm{O}$ fluxes during the spring which were associated with precipitation events in a study in Quebec. In our study, we did not find significant correlations between soil $\mathrm{N}_{2} \mathrm{O}$ fluxes and soil temperature and moisture conditions during measurements.

Mean $\mathrm{N}_{2} \mathrm{O}$ fluxes over seasons during the study period show that $\mathrm{CT}$ and grass fallow plots had net emissions of 2.31 and $21.42 \mathrm{~g} \mathrm{~N}_{2} \mathrm{O} \mathrm{ha}^{-1}$ day $^{-1}$, respectively, whereas plots under NT system were net sinks of atmospheric $\mathrm{N}_{2} \mathrm{O}$ with a mean flux rate of $-21.84 \mathrm{~g} \mathrm{~N}_{2} \mathrm{O} \mathrm{ha}^{-1}$ day $^{-1}$ (Table 4). Our study on the Decatur silt loam soil in north Alabama therefore shows that while CT system can be an insignificant source of soil $\mathrm{CH}_{4}$, it can be a significant source of soil $\mathrm{N}_{2} \mathrm{O}$ which is a more potent greenhouse gas than
$\mathrm{CH}_{4}$. On the other hand, an NT cropping system can reduce the agricultural contribution of both $\mathrm{CH}_{4}$ and $\mathrm{N}_{2} \mathrm{O}$, since plots under NT were sinks of $\mathrm{CH}_{4}$ and $\mathrm{N}_{2} \mathrm{O}$. In the Midwest, Kessavalou et al. [49] reported that an NT fallow system exhibited the least threat to cause the deterioration of atmospheric quality due to greater $\mathrm{CH}_{4}$ uptake and decreased $\mathrm{N}_{2} \mathrm{O}$ emissions.

Contrary to our findings, Almaraz et al. [48] suggested that changing from CT to NT system under the heavy soil conditions of Quebec may increase greenhouse gas contributions mainly as result of the increase in $\mathrm{N}_{2} \mathrm{O}$ emission. However, the above authors indicated that this negative effect of NT could be reduced by avoiding fertilizer application during high precipitation periods, thus indicating that the results were mainly due to the effect of soil moisture conditions at fertilizer application time. As reported by Mosier et al. [43], $\mathrm{N}_{2} \mathrm{O}$ emissions can be variable depending on soil moisture conditions, $\mathrm{N}$ mineralization, and plant community dynamics, which can explain the variability in reported findings on effect of tillage systems on $\mathrm{N}_{2} \mathrm{O}$ emissions.

Plots which received AN-SI, PL-SA, and PL-BA had $\mathrm{N}_{2} \mathrm{O}$ emissions of $240.25,20.51$, and $19.20 \mathrm{~g} \mathrm{~N}_{2} \mathrm{O} \mathrm{ha}{ }^{-1} \mathrm{day}^{-1}$, respectively, in spring, whereas plots which received AN-SA, PL-SI, and the control plots were $\mathrm{N}_{2} \mathrm{O}$ sinks (Table 4). There was no significant difference in soil $\mathrm{N}_{2} \mathrm{O}$ fluxes between plots which received PL-SA and PL-BA in spring. In summer, plots which received AN-SA, AN-SI, and PL-BA and the control plots were net sinks of $\mathrm{N}_{2} \mathrm{O}$, whereas plots which received PL-SI and PL-SA had $\mathrm{N}_{2} \mathrm{O}$ emissions of 86.43 and $117.09 \mathrm{~g}$ $\mathrm{N}_{2} \mathrm{O}$ ha $^{-1}$ day $^{-1}$, respectively. In fall, plots which received AN-SA, PL-SA, and PL-BA and the control plots were sinks of $\mathrm{N}_{2} \mathrm{O}$, whereas plots which received AN-SI and PL-SI had $\mathrm{N}_{2} \mathrm{O}$ emissions of 211.48 and $168.32 \mathrm{~g} \mathrm{~N}_{2} \mathrm{O} \mathrm{ha}^{-1}$ day $^{-1}$, respectively (Table 4). In winter, plots which received PL-SA, $150 \mathrm{~kg} \mathrm{Nha}^{-1} \mathrm{PL}-\mathrm{BA}$, and the control plots were sinks of $\mathrm{N}_{2} \mathrm{O}$, whereas plots which received AN-SA, AN-SI, and PL-SI had large $\mathrm{N}_{2} \mathrm{O}$ emissions of 735.00, 89.40, and $186.98 \mathrm{~g} \mathrm{~N}_{2} \mathrm{O}$ ha $^{-1}$ day $^{-1}$, respectively (Table 4 ).

Averaged over tillage and $\mathrm{N}$ fertilizer treatments, $\mathrm{N}_{2} \mathrm{O}$ oxide emissions of 32.14 and $21.37 \mathrm{~g} \mathrm{~N}_{2} \mathrm{O}$ ha $^{-1}$ day $^{-1}$ were observed in spring and winter, whereas in summer and fall, the plots were sinks of $\mathrm{N}_{2} \mathrm{O}$ with fluxes of -30.23 and $-7.23 \mathrm{~g} \mathrm{~N}_{2} \mathrm{O}$ ha $^{-1}$ day $^{-1}$, respectively (Table 4 ). Mean soil $\mathrm{N}_{2} \mathrm{O}$ fluxes in each $\mathrm{N}$ fertilizer treatment averaged over seasons during the study period show that the $0 \mathrm{~N}$ control and the PL-BA treatments were huge net sinks of $\mathrm{N}_{2} \mathrm{O}$ with a flux of about $-141.63 \mathrm{~g} \mathrm{~N}_{2} \mathrm{O} \mathrm{ha}^{-1}$ day $^{-1}$, whereas all plots under inorganic AN fertilizer treatments, the PL-SA, and the PL-SI treatments had net $\mathrm{N}_{2} \mathrm{O}$ emissions (Table 4). The three highest cumulative soil $\mathrm{N}_{2} \mathrm{O}$ emissions were observed in plots which received AN-SA $\left(173.68 \mathrm{~g} \mathrm{~N}_{2} \mathrm{O} \mathrm{ha}^{-1}\right.$ day $\left.^{-1}\right)$, PL-SI $\left(100.55 \mathrm{~g} \mathrm{~N}_{2} \mathrm{O} \mathrm{ha}^{-1}\right.$ day $\left.^{-1}\right)$ and AN-SI $\left(55.19 \mathrm{~g} \mathrm{~N}_{2} \mathrm{O}\right.$ ha $^{-1}$ day $\left.^{-1}\right)$.

The amounts of $\mathrm{N}_{2} \mathrm{O}$ emitted from soils depend on complex interactions between soil properties (such as soil aeration status, temperature and carbon availability, soil texture), type and management of $\mathrm{N}$ fertilizer preceding crop, residue management, and other agricultural practices as well as prevailing climatic conditions [50,51]. Despite being a source 


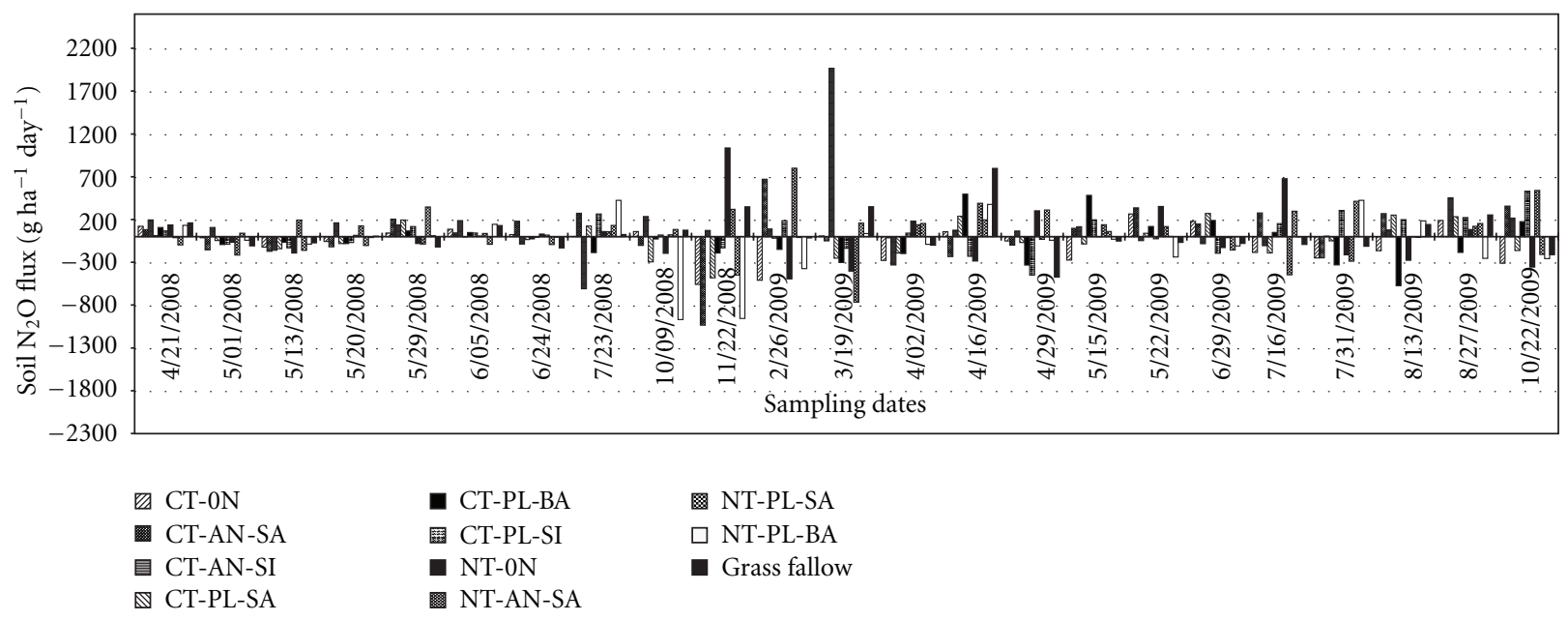

Figure 3: Soil $\mathrm{N}_{2} \mathrm{O}$ fluxes in corn plots receiving ammonium nitrate (AN) and poultry litter (PL) N fertilizers using surface (SA), soil incorporation (SI), and subsurface band (BA) application methods in conventional tillage (CT) and no-tillage (NT), systems, Hazel Green, Alabama.

TABLE 4: Soil $\mathrm{N}_{2} \mathrm{O}$ fluxes as influenced by tillage systems and ammonium nitrate (AN) and poultry litter (PL) N fertilizers using surface (SA), soil incorporation (SI), and subsurface band (BA) application methods in spring, summer, fall, and winter seasons, Hazel Green, Alabama.

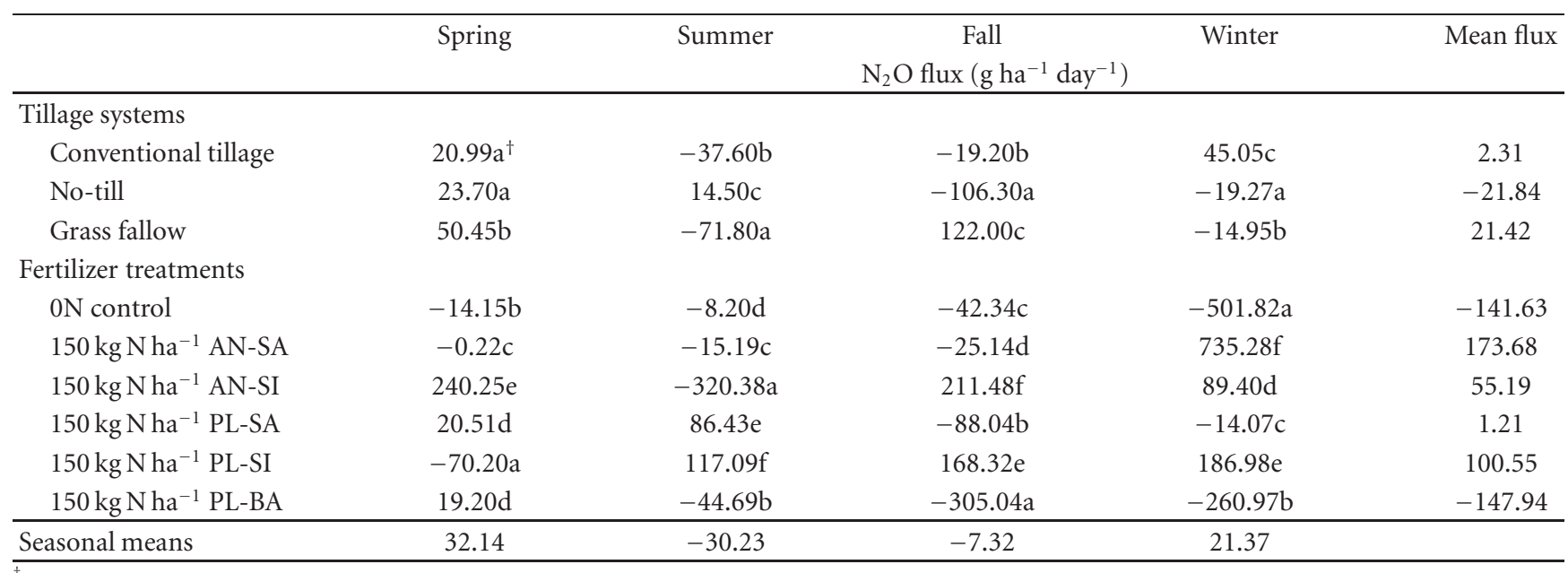

${ }^{\dagger}$ Means for tillage system or $\mathrm{N}$ fertilizer treatment within a season followed by the same letter are not significantly different at the $P \leq 0.05$ level.

of $\mathrm{N}_{2} \mathrm{O}$, the soil can also remove atmospheric $\mathrm{N}_{2} \mathrm{O}$ under conditions favorable for $\mathrm{N}_{2} \mathrm{O}$ reduction [52, 53]. Although this is probably only a minor sink on the global scale, the elimination of $\mathrm{N}_{2} \mathrm{O}$ in the stratosphere is so slow that even a small soil sink can contribute significantly to reduce the atmospheric residence time of $\mathrm{N}_{2} \mathrm{O}$ [51]. The current lack of literature documenting the behavior of soils acting as sinks of $\mathrm{N}_{2} \mathrm{O}$ is most probably due to the fact that current studies in agricultural ecosystems are not only designed to but are also more focused on measuring soil, emissions of $\mathrm{N}_{2} \mathrm{O}$ as opposed to soil $\mathrm{N}_{2} \mathrm{O}$ uptake, since emissions are linked to climate change.

Our results clearly show that plots which received AN fertilizer were net emitters of soil $\mathrm{N}_{2} \mathrm{O}$ irrespective of application method. Nitrous oxide is produced in soils as an intermediate during nitrification and denitrification processes $[11,54,55]$. Therefore $\mathrm{N}$ application, especially, inorganic fertilizer sources in which $\mathrm{NO}_{3}-\mathrm{N}$ is readily available in the soil can generally result in more $\mathrm{N}_{2} \mathrm{O}$ emissions compared to control plots, as indicated by high $\mathrm{N}_{2} \mathrm{O}$ fluxes in plots which received $150 \mathrm{~kg} \mathrm{~N} \mathrm{ha}^{-1}$ AN using surface or soil incorporation application methods. Similarly, on a clay soil in Canada, Chantigny et al. [56] found significantly greater cumulative soil $\mathrm{N}_{2} \mathrm{O}-\mathrm{N}$ emissions with mineral fertilizer treated soil compared to liquid swine manure, which is also an indication that soil $\mathrm{N}_{2} \mathrm{O}$ production is primarily driven by availability of $\mathrm{NO}_{3}-\mathrm{N}$ in the soil. Although $\mathrm{N}$ fertilizer in the form of PL using soil incorporation (150 $\left.\mathrm{kg} \mathrm{N} \mathrm{ha}^{-1} \mathrm{PL}-\mathrm{SI}\right)$ application method had a negative mean soil $\mathrm{CH}_{4}$ flux of $-14.97 \mathrm{~g}$ $\mathrm{CH}_{4}$ ha $^{-1}$ day $^{-1}$, the high mean $\mathrm{N}_{2} \mathrm{O}$ emissions of $100.55 \mathrm{~g}$ $\mathrm{N}_{2} \mathrm{O}$ ha $^{-1}$ day $^{-1}$ show that this treatment is not sustainable. On the other hand, subsurface band application of PL resulted in net negative $\mathrm{CH}_{4}$ and $\mathrm{N}_{2} \mathrm{O}$ fluxes of $-8.36 \mathrm{~g} \mathrm{CH}_{4}$ $\mathrm{ha}^{-1}$ day $^{-1}$ and $-147.94 \mathrm{~g} \mathrm{~N}_{2} \mathrm{O} \mathrm{ha}{ }^{-1}$ day $^{-1}$, indicating that 
subsurface band application of PL can be a sustainable poultry waste management practice for reducing agricultural greenhouse gas contributions to the atmosphere.

Interestingly, plots with surface application of PL (PL-SA treatment), which is the standard practice for PL application in NT system, were net sinks of $\mathrm{CH}_{4}$ and small emitters of soil $\mathrm{N}_{2} \mathrm{O}$ over the study period. This suggests that given the other benefits of PL such as supplying nutrients for plant growth, improving soil quality through direct addition of $\mathrm{C}$ and $\mathrm{N}$ to the soil [1], surface application of PL in cover crop residues could be more environmentally sound compared to soil incorporation. However, the extra benefits of significantly higher $\mathrm{CH}_{4}$ and $\mathrm{N}_{2} \mathrm{O}$ uptake observed with subsurface band application of PL far out-weigh the benefits of surface application of PL, which implies that subsurface band application could be the best animal waste management strategy for reducing agricultural greenhouse gas emissions.

Under anaerobic or high soil moisture conditions, $\mathrm{NO}_{3}-$ $\mathrm{N}$ from $\mathrm{N}$ fertilization with an organic fertilizer such as $\mathrm{PL}$ can be associated with an increased rate of $\mathrm{N}_{2} \mathrm{O}$ production from denitrification thereby resulting in soil emissions of $\mathrm{N}_{2} \mathrm{O}$. In order for $\mathrm{N}_{2} \mathrm{O}$ production from denitrification to be significant, $\mathrm{O}_{2}$ consumption by soil microbes must exceed $\mathrm{O}_{2}$ diffusion into the soil, thereby creating microsites of anaerobiosis [57]. Organic matter in animal manure can increase percent water-filled pore spaces in mineral soils which can reduce soil aeration and decrease $\mathrm{O}_{2}$ diffusion into the soil thereby leading to anaerobic conditions. Linn and Doran [29] found that higher percentage of water-filled pores in NT soils was reflected in higher $\mathrm{N}_{2} \mathrm{O}$ production and that $\mathrm{N}$ fertilization increased $\mathrm{N}_{2} \mathrm{O}$ production irrespective of tillage system.

In this study, we found that $\mathrm{N}_{2} \mathrm{O}$ emissions directly above the PL band were generally higher compared to those where the PL was mixed with the soil under SA or SI methods, that is, where there was no PL band. This is due to the fact that subsurface band application of PL application concentrates the PL in a narrow strip $(4.4 \mathrm{~cm}$ wide) at a depth of about $7 \mathrm{~cm}$ under the soil surface at a $97 \mathrm{~cm}$ band spacing. This increases the amount of $\mathrm{C}$ and $\mathrm{N}$ substrates in a confined area, hence an increase in the amount of $\mathrm{NO}_{3}$ from mineralization of the PL. Poultry litter also causes the soil to hold more water and retain the moisture longer and thereby increasing both the rate of mineralization and the percent water-filled pore space, which promotes anaerobic conditions which promote $\mathrm{N}_{2} \mathrm{O}$ production from denitrification. However, despite the higher $\mathrm{N}_{2} \mathrm{O}$ emissions directly above the PL band, the "effective" per plot $\mathrm{N}_{2} \mathrm{O}$ fluxes, taking into account the fact that the PL bands cover only narrow strips of soil in the plots, were significantly lower than $\mathrm{N}_{2} \mathrm{O}$ fluxes in plots which received PL using the soil incorporation method.

Engel et al. [58] reported that placement of urea fertilizer in nests or bands resulted in delayed but prolonged soil $\mathrm{N}_{2} \mathrm{O}$ emissions compared to surface broadcast applications on an Amsterdam silt loam soil in Montana. On a Waukegan silt loam soil in Minnesota, Venterea et al. [47] reported that surface broadcasting urea in an NT system resulted in higher $\mathrm{N}_{2} \mathrm{O}$ emissions compared to $\mathrm{CT}$, whereas soil injection of anhydrous ammonia resulted in higher $\mathrm{N}_{2} \mathrm{O}$ emissions under CT system. Alluvione et al. [59] found that the slow mineralization of composted manure in spring reduced $\mathrm{N}_{2} \mathrm{O}$ emissions compared to urea fertilizer and that after combining $\mathrm{N}_{2} \mathrm{O}$ and $\mathrm{CO}_{2}$ fluxes, compost reduced the $\mathrm{CO}_{2}$ equivalent emissions by $49 \%$ compared to urea application. Rochette et al. [60] found double $\mathrm{N}_{2} \mathrm{O}$ emissions in NT plots compared to tilled plots in heavy clay soils but found no difference between tillage systems on loam soils.

Some studies have reported higher $\mathrm{N}_{2} \mathrm{O}$ emissions in NT compared to CT cropping systems [61-63], while some studies have found lower emissions in NT soils or no difference between tillage systems [64, 65]. Sistani et al. [66] reported that application of effluent liquid manure below the soil surface by injection resulted in elevated $\mathrm{CH}_{4}$ emissions compared to the control treatment, while Drury et al. [67] found that reduced tillage and shallow $\mathrm{N}$ placement depth reduced $\mathrm{N}_{2} \mathrm{O}$ emissions on a clay loam soils in eastern Canada. The variations in research findings discussed above suggest that soil and fertilizer management practices can result in different responses in soil emissions of greenhouse gases depending on soil type, fertilizer type, and soil environmental conditions. Therefore, site-specific tillage and fertilizer management practices for different locations need to be developed and evaluated in order to achieve the goal of reducing agricultural greenhouse gas emissions at local, regional, and global scales.

\section{Conclusion}

There were significant seasonal variations in soil $\mathrm{CH}_{4}$ and $\mathrm{N}_{2} \mathrm{O}$ emissions among tillage and $\mathrm{N}$ fertilizer treatments in corn plots in north Alabama. Mean soil $\mathrm{CH}_{4}$ fluxes over seasons during the two-year study period in CT and NT systems were not significantly different. Mean soil $\mathrm{CH}_{4}$ and $\mathrm{N}_{2} \mathrm{O}$ fluxes averaged over tillage and $\mathrm{N}$ fertilizer treatments and seasons showed that the plots were net sinks of $\mathrm{CH}_{4}$ and net emitters of $\mathrm{N}_{2} \mathrm{O}$ over the two-year study period. Averaged over seasons, plots under NT were net sinks of soil $\mathrm{N}_{2} \mathrm{O}$, while CT plots and grass fallow plots were net emitters of soil $\mathrm{N}_{2} \mathrm{O}$. Plots which received AN fertilizer were net emitters of soil $\mathrm{CH}_{4}$ and $\mathrm{N}_{2} \mathrm{O}$, during the study period, irrespective of application method, whereas plots which received $\mathrm{PL}$ fertilizer were net sinks of $\mathrm{CH}_{4}$, irrespective of application method. Plots which received PL using surface or soil incorporation application methods were net emitters of $\mathrm{N}_{2} \mathrm{O}$, while plots which received PL using subsurface band application method were net sinks of $\mathrm{N}_{2} \mathrm{O}$. Our study indicates that using subsurface band application of PL was the most promising environmentally sustainable poultry waste application method for reducing $\mathrm{CH}_{4}$ and $\mathrm{N}_{2} \mathrm{O}$ emissions from agricultural soil in NT and CT corn production systems on the Decatur soil in north Alabama.

\section{Acknowledgments}

Financial support for this project was provided by the USDA/ National Institute of Food and Agriculture, Competitive Grant no. 2007-35112 17857. The authors would like to 
extend their thanks and appreciation to the staff at the Winfred Thomas Agricultural Experiment Station at Hazel Green Alabama for assisting in tillage operations and various other project activities.

\section{References}

[1] E. Z. Nyakatawa, K. C. Reddy, and K. R. Sistani, “Tillage, cover cropping, and poultry litter effects on selected soil chemical properties," Soil and Tillage Research, vol. 58, no. 1-2, pp. 6979, 2001.

[2] U. M. Sainju, Z. N. Senwo, E. Z. Nyakatawa, I. A. Tazisong, and K. C. Reddy, "Tillage, cropping systems, and nitrogen fertilizer source effects on soil carbon sequestration and fractions," Journal of Environmental Quality, vol. 37, no. 3, pp. 880-888, 2008.

[3] D. B. Watts, H. A. Torbert, S. A. Prior, and G. Huluka, "Longterm tillage and poultry litter impacts soil carbon and nitrogen mineralization and fertility," Soil Science Society of America Journal, vol. 74, no. 4, pp. 1239-1247, 2010.

[4] W. Bickert, "Air quality and agriculture," Michigan Dairy Review, vol. 9, no. 3, pp. 1-3, 2004.

[5] Energy Information Administration, "Emissions of greenhouse gases report," Tech. Rep. DOE/EIA-0573, U.S. Energy Information Administration, Washington, DC, USA, 2011.

[6] C. Roelandt, B. van Wesemael, and M. Rounsevell, "Estimating annual $\mathrm{N}_{2} \mathrm{O}$ emissions from agricultural soils in temperate climates," Global Change Biology, vol. 11, no. 10, pp. 17011711, 2005.

[7] M. H. Beare, E. G. Gregorich, and P. St-Georges, "Compaction effects on $\mathrm{CO}_{2}$ and $\mathrm{N}_{2} \mathrm{O}$ production during drying and rewetting of soil," Soil Biology and Biochemistry, vol. 41, no. 3, pp. 611-621, 2009.

[8] A. S. K. Chan and T. B. Parkin, "Methane oxidation and production activity in soils from natural and agricultural ecosystems," Journal of Environmental Quality, vol. 30, no. 6, pp. 1896-1903, 2001.

[9] R. Conrad, "Soil microbial processes involved in production and consumption of atmospheric trace gases," in Advances in Microbial Ecology, J. G. Jones, Ed., Plenum Press, New York, NY, USA, 1995.

[10] J. P. Schimel and J. Gulledge, "Microbial community structure and global trace gases," Global Change Biology, vol. 4, no. 7, pp. 745-758, 1998.

[11] G. L. Hutchinson and E. A. Davidson, "Processes for production and consumption of gaseous nitrogen oxides in soil," in Agricultural Ecosystem Effects on Trace Gases and Global Climate Change, L. A. Harper, Ed., no. 55, pp. 79-93, American Society of Agronomy, Madison, Wis, USA, 1993.

[12] S. C. Jarvis, D. J. Hatch, B. F. Pain, and J. V. Klarenbeek, "Denitrification and the evolution of nitrous oxide after the application of cattle slurry to a peat soil," Plant and Soil, vol. 166, no. 2, pp. 231-241, 1994.

[13] S. G. Sommer, R. R. Sherlock, and R. Z. Khan, "Nitrous oxide and methane emissions from pig slurry amended soils," Soil Biology and Biochemistry, vol. 28, no. 10-11, pp. 1541-1544, 1996.

[14] S. O. Petersen, "Nitrous oxide emissions from manure and inorganic fertilizers applied to spring barley," Journal of Environmental Quality, vol. 28, no. 5, pp. 1610-1618, 1999.

[15] S. G. Sommer and N. J. Hutchings, "Ammonia emission from field applied manure and its reduction-invited paper," European Journal of Agronomy, vol. 15, no. 1, pp. 1-15, 2001.
[16] H. Akiyama and H. Tsuruta, "Nitrous oxide, nitric oxide, and nitrogen dioxide fluxes from soils after manure and urea application," Journal of Environmental Quality, vol. 32, no. 2, pp. 423-431, 2003.

[17] A. D. Halvorson, S. J. del Grosso, and C. A. Reule, "Nitrogen, tillage, and crop rotation effects on nitrous oxide emissions from irrigated cropping systems," Journal of Environmental Quality, vol. 37, no. 4, pp. 1337-1344, 2008.

[18] M. L. Cabrera, S. C. Chiang, W. C. Merka, O. C. Pancorbo, and S. A. Thompson, "Nitrous oxide and carbon dioxide emissions from pelletized and nonpelletized poultry litter incorporated into soil," Plant and Soil, vol. 163, no. 2, pp. 189-196, 1994.

[19] R. R. Sharpe, H. H. Schomberg, L. A. Harper, D. M. Endale, M. B. Jenkins, and A. J. Franzluebbers, "Ammonia volatilization from surface-applied poultry litter under conservation tillage management practices," Journal of Environmental Quality, vol. 33, no. 4, pp. 1183-1188, 2004.

[20] P. A. Jacinthe and W. A. Dick, "Soil management and nitrous oxide emissions from cultivated fields in southern Ohio," Soil \& Tillage Research, vol. 41, no. 3-4, pp. 221-235, 1997.

[21] R. F. Spalding and M. E. Exner, "Occurrence of nitrate in groundwater-a review," Journal of Environmental Quality, vol. 22, no. 3, pp. 392-402, 1993.

[22] H. Flessa, R. Ruser, P. Dörsch et al., "Integrated evaluation of greenhouse gas emissions $\left(\mathrm{CO}_{2}, \mathrm{CH}_{4}, \mathrm{~N}_{2} \mathrm{O}\right)$ from two farming systems in southern Germany," Agriculture, Ecosystems and Environment, vol. 91, no. 1-3, pp. 175-189, 2002.

[23] T. R. Way, M. R. Siegford, and D. E. Rowe, "Applicator system and method for the agricultural distribution of biodegradable and non-biodegradable materials," U.S. Patent no. 7,721,662, 2010.

[24] USDA-ARS GRACEnet Chamber-based Trace Gas Flux Measurement Protocol, 2003, http://www.ars.usda.gov/ SP2UserFiles/person/31831/2003GRACEnetTraceGasProtocol .pdf.

[25] G. L. Hutchinson and G. P. Livingston, "Use of chamber systems to measure trace gas fluxes," in Agro-Ecosytem Effect on Radiatively Important Trace Gases and Climate Change, L. A. Harper, A. R. Moiser, J. M. Duxbury, and D. E. Rolston, Eds., vol. 55, pp. 63-78, American Society of Agronomy, Madison, Wis, USA, 1993.

[26] T. R. Way, D. B. Watts, K. E. Smith, and H. A. Torbert, "Calculation of effective gas flux from soil following band application of manure or fertilizer," Transactions of the American Society of Agricultural and Biological Engineering, vol. 54, no. 1, pp. 337345, 2011.

[27] R. G. D. Steel and J. H. Torrie, Principles and Procedures of Statistics, McGraw-Hill, New York, NY, USA, 2nd edition, 1980.

[28] SAS Institute, "SAS system for personal computers," Tech. Rep. 9.03, SAS Institute, Cary, NC, USA, 2003.

[29] D. M. Linn and J. W. Doran, "Effect of water-filled pore space on carbon dioxide and nitrous oxide production in tilled and nontilled soils," Soil Science Society of America Journal, vol. 48, no. 6, pp. 1267-1272, 1984.

[30] S. M. Castaldi, M. Costantini, P. Cenciarelli, P. Ciccioli, and R. Valentini, "The methane sink associated to soils of natural and agricultural ecosystems in Italy," Chemosphere, vol. 66, no. 4, pp. 723-729, 2007.

[31] J. M. F. Johnson, D. Archer, and N. Barbour, "Greenhouse gas emission from contrasting management scenarios in the northern Corn Belt," Soil Science Society of America Journal, vol. 74, no. 2, pp. 396-406, 2010. 
[32] F. Alluvione, A. D. Halvorson, and S. J. del Grosso, "Nitrogen, tillage, and crop rotation effects on carbon dioxide and methane fluxes from irrigated cropping systems," Journal of Environmental Quality, vol. 38, no. 5, pp. 2023-2033, 2009.

[33] M. Bender and R. Conrad, "Effect of $\mathrm{CH}_{4}$ concentrations and soil conditions on the induction of $\mathrm{CH}_{4}$ oxidation activity," Soil Biology and Biochemistry, vol. 27, no. 12, pp. 1517-1527, 1995.

[34] D. S. Powlson, K. W. T. Goulding, T. W. Willison, C. P. Webster, and B. W. Hütsch, "The effect of agriculture on methane oxidation in soil," Nutrient Cycling in Agroecosystems, vol. 49, no. 1-3, pp. 59-70, 1997.

[35] A. R. Mosier, J. A. Delgado, V. L. Cochran, D. W. Valentine, and W. J. Parton, "Impact of agriculture on soil consumption of atmospheric $\mathrm{CH}_{4}$ and a comparison of $\mathrm{CH}_{4}$ and $\mathrm{N}_{2} \mathrm{O}$ flux in subarctic, temperate and tropical grasslands," Nutrient Cycling in Agroecosystems, vol. 49, no. 1-3, pp. 71-83, 1997.

[36] E. Topp and E. Pattey, "Soils as sources and sinks for atmospheric methane," Canadian Journal of Soil Science, vol. 77, no. 2, pp. 167-178, 1997.

[37] M. A. Liebig, J. R. Gross, S. L. Kronberg, R. L. Phillips, and J. D. Hanson, "Grazing management contributions to net global warming potential: a long-term evaluation in the northern great plains," Journal of Environmental Quality, vol. 39, no. 3, pp. 799-809, 2010.

[38] R. S. Hanson and T. E. Hanson, "Methanogenic bacteria," Microbiology and Molecular Biology Reviews, vol. 60, no. 2, pp. 439-471, 1996.

[39] S. R. Mohanty, P. L. E. Bodelier, V. Floris, and R. Conrad, "Differential effects of nitrogenous fertilizers on methaneconsuming microbes in rice field and forest soils," Applied and Environmental Microbiology, vol. 72, no. 2, pp. 1346-1354, 2006.

[40] C. Bédard and R. Knowles, "Physiology, biochemistry, and specific inhibitors of $\mathrm{CH}_{4}, \mathrm{NH}_{4}^{+}$, and $\mathrm{CO}$ oxidation by methanotrophs and nitrifiers," Microbiology and Molecular Biology Reviews, vol. 53, no. 1, pp. 68-84, 1989.

[41] M. R. Hyman and P. M. Wood, "Methane oxidation by Nitrosomonas europaea," Biochemical Journal, vol. 212, no. 1, pp. 31-37, 1983.

[42] P. A. Steudler, R. D. Bowden, J. M. Melillo, and J. D. Aber, "Influence of nitrogen fertilization on methane uptake in temperate forest soils," Nature, vol. 341, no. 6240, pp. 314-316, 1989.

[43] A. Mosier, D. Schimel, D. Valentine, K. Bronson, and W. Parton, "Methane and nitrous oxide fluxes in native, fertilized and cultivated grasslands," Nature, vol. 350, no. 6316, pp. 330332, 1991.

[44] K. F. Bronson and A. R. Mosier, "Suppression of methane oxidation in aerobic soil by nitrogen fertilizers, nitrification inhibitors, and urease inhibitors," Biology and Fertility of Soils, vol. 17, no. 4, pp. 263-268, 1994.

[45] D. R. Nayak, Y. J. Babu, A. Datta, and T. K. Adhya, "Methane oxidation in an intensively cropped tropical rice field soil under long-term application of organic and mineral fertilizers," Journal of Environmental Quality, vol. 36, no. 6, pp. 1577-1584, 2007.

[46] G. Hernandez-Ramirez, S. M. Brouder, D. R. Smith, and G. E. van Scoyoc, "Greenhouse gas fluxes in an eastern corn belt soil: weather, nitrogen source, and rotation," Journal of Environmental Quality, vol. 38, no. 3, pp. 841-854, 2009.

[47] R. T. Venterea, M. Burger, and K. A. Spokas, "Nitrogen oxide and methane emissions under varying tillage and fertilizer management," Journal of Environmental Quality, vol. 34, no. 5, pp. 1467-1477, 2005.
[48] J. J. Almaraz, F. Mabood, X. Zhou et al., "Carbon dioxide and nitrous oxide fluxes in corn grown under two tillage systems in southwestern Quebec," Soil Science Society of America Journal, vol. 73, no. 1, pp. 113-119, 2009.

[49] A. Kessavalou, A. R. Mosier, J. W. Doran, R. A. Drijber, D. J. Lyon, and O. Heinemeyer, "Fluxes of carbon dioxide, nitrous oxide, and methane in grass sod and winter wheat-fallow tillage management," Journal of Environmental Quality, vol. 27, no. 5, pp. 1094-1104, 1998.

[50] P. Szarlip, Release and uptake of nitrous oxide in some mineral soils, Ph.D. thesis, Institute of Agrophysics, Polish Academy of Sciences, Lublin, Poland, 2009.

[51] P. Szarlip, T. Włodarczyk, M. Brzezińska, and J. Gliński, "Production and uptake of nitrous oxide $\left(\mathrm{N}_{2} \mathrm{O}\right)$ as affected by soil conditions," Acta Agrophysica, vol. 187, no. 8, pp. 1-65, 2010.

[52] A. M. Blackmer and J. M. Bremner, "Potential of soil as a sink for atmospheric nitrous oxide," Geophysical Research Letters, vol. 3, no. 12, pp. 739-742, 1976.

[53] A. D. Matthias, A. M. Blackmer, and J. M. Bremner, "Diurnal variability in the concentration of nitrous oxide in surface air," Geophysical Research Letters, vol. 6, no. 6, pp. 441-443, 1979.

[54] E. A. Davidson, W. T. Swank, and T. O. Perry, "Distinguishing between nitrification and denitrification as sources of gaseous nitrogen production in soil," Applied and Environmental Microbiology, vol. 52, no. 6, pp. 1280-1286, 1986.

[55] M. Maag and F. P. Vinther, "Nitrous oxide emission by nitrification and denitrification in different soil types and at different soil moisture contents and temperatures," Applied Soil Ecology, vol. 4, no. 1, pp. 5-14, 1996.

[56] M. H. Chantigny, P. Rochette, D. A. Angers et al., "Soil nitrous oxide emissions following band-incorporation of fertilizer nitrogen and swine manure," Journal of Environmental Quality, vol. 39, no. 5, pp. 1545-1553, 2010.

[57] E. A. Davidson and W. T. Swank, "Nitrous oxide dissolved in soil solution: an insignificant pathway of nitrogen loss from a southeastern hardwood forest," Water Resources Research, vol. 26, no. 7, pp. 1687-1690, 1990.

[58] R. Engel, D. L. Liang, R. Wallander, and A. Bembenek, "Influence of urea fertilizer placement on nitrous oxide production from a silt loam soil," Journal of Environmental Quality, vol. 39, no. 1, pp. 115-125, 2010.

[59] F. Alluvione, C. Bertora, L. Zavattaro, and C. Grignani, "Nitrous oxide and carbon dioxide emissions following green manure and compost fertilization in corn," Soil Science Society of America Journal, vol. 74, no. 2, pp. 384-395, 2010.

[60] P. Rochette, D. A. Angers, M. H. Chantigny, and N. Bertrand, "Nitrous oxide emissions respond differently to no-till in a loam and a heavy clay soil," Soil Science Society of America Journal, vol. 72, no. 5, pp. 1363-1369, 2008.

[61] A. F. MacKenzie, M. X. Fan, and F. Cadrin, "Nitrous oxide emission as affected by tillage, corn-soybean-alfalfa rotations and nitrogen fertilization," Canadian Journal of Soil Science, vol. 77, no. 2, pp. 145-152, 1997.

[62] B. C. Ball, A. Scott, and J. P. Parker, "Field $\mathrm{N}_{2} \mathrm{O}, \mathrm{CO}_{2}$ and $\mathrm{CH}_{4}$ fluxes in relation to tillage, compaction and soil quality in Scotland," Soil and Tillage Research, vol. 53, no. 1, pp. 2939, 1999.

[63] E. M. Baggs, M. Stevenson, M. Pihlatie, A. Regar, H. Cook, and G. Cadisch, "Nitrous oxide emissions following application of residues and fertiliser under zero and conventional tillage," Plant and Soil, vol. 254, no. 2, pp. 361-370, 2003.

[64] G. P. Robertson, E. A. Paul, and R. R. Harwood, "Greenhouse gases in intensive agriculture: contributions of individual gases 
to the radiative forcing of the atmosphere," Science, vol. 289, no. 5486 , pp. $1922-1925,2000$

[65] A. A. Elmi, C. Madramootoo, C. Hamel, and A. Liu, "Denitrification and nitrous oxide to nitrous oxide plus dinitrogen ratios in the soil profile under three tillage systems," Biology and Fertility of Soils, vol. 38, no. 6, pp. 340-348, 2003.

[66] K. R. Sistani, J. G. Warren, N. Lovanh, S. Higgins, and S. Shearer, "Greenhouse gas emissions from swine effluent applied to soil by different methods," Soil Science Society of America Journal, vol. 74, no. 2, pp. 429-435, 2010.

[67] C. F. Drury, W. D. Reynolds, C. S. Tan, T. W. Welacky, W. Calder, and N. B. McLaughlin, "Emissions of nitrous oxide and carbon dioxide: influence of tillage type and nitrogen placement depth," Soil Science Society of America Journal, vol. 70 , no. 2 , pp. $570-581,2006$. 

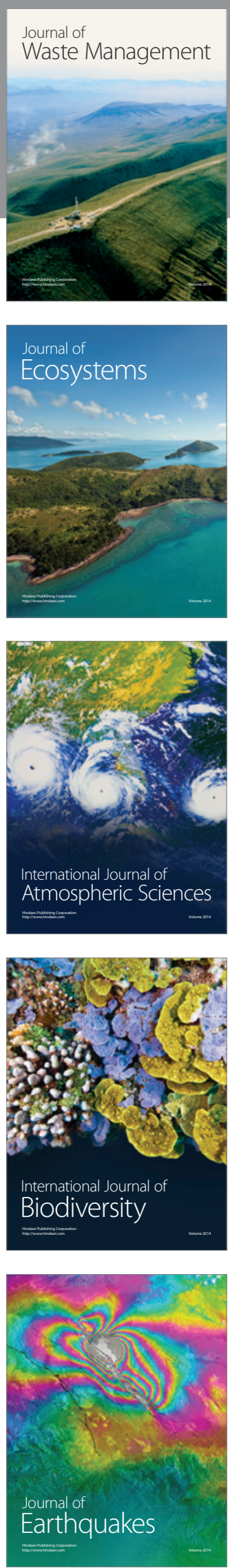
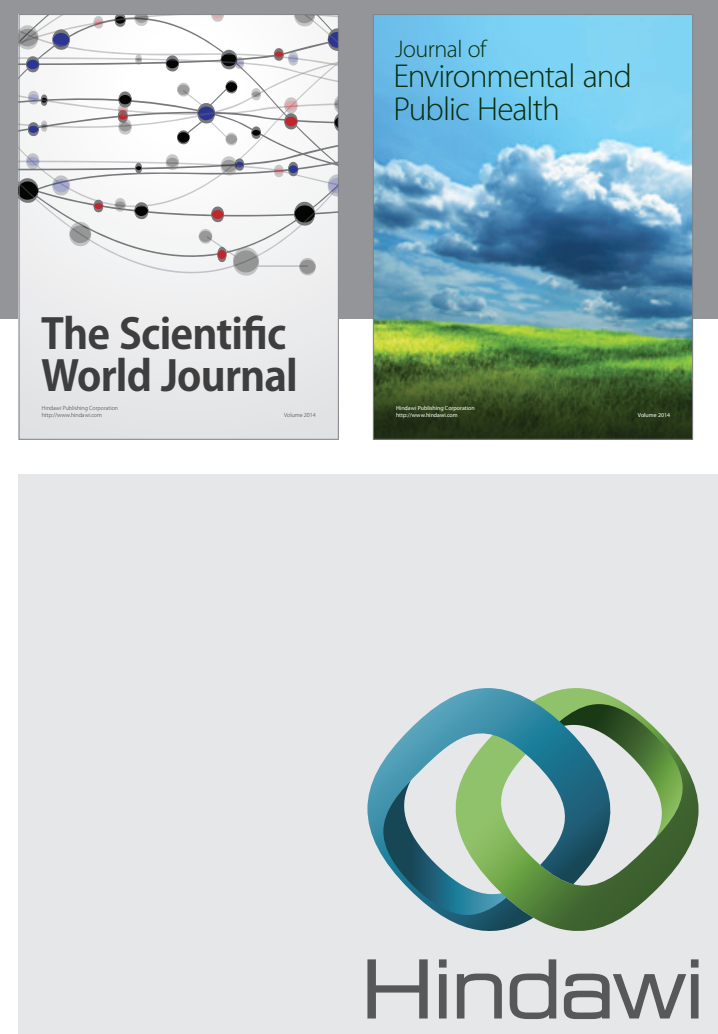

Submit your manuscripts at

http://www.hindawi.com
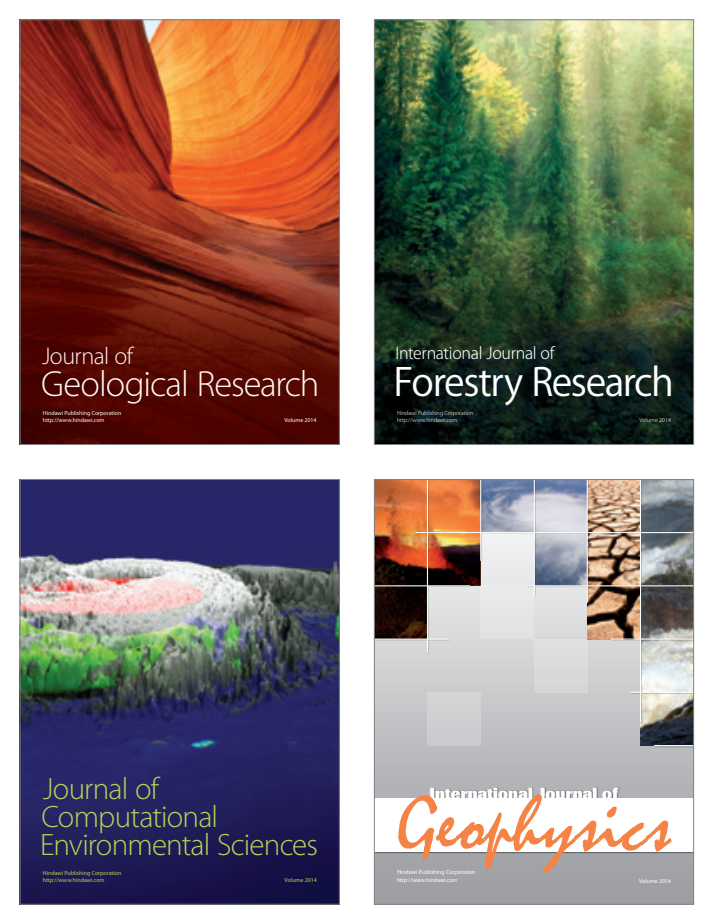
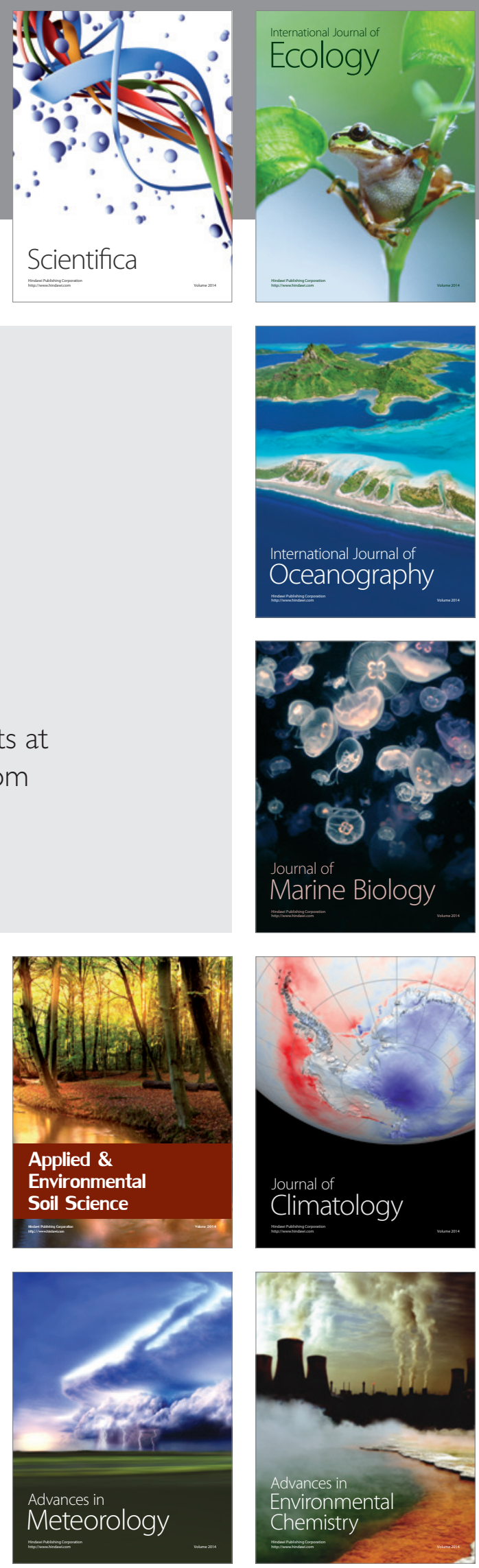